Nova Southeastern University

Florida

NOVA SOUTHEASTERN

UNIVERSITY

NSUWorks

Marine \& Environmental Sciences Faculty Articles Department of Marine and Environmental Sciences

$1-1-2006$

\title{
Metabolites from the Marine-Derived Fungus Chromocleista sp. Isolated from a Deep-Water Sediment Sample Collected in the Gulf of Mexico
}

Young Chul Park

Harbor Branch Oceanographic Institution

Sarath P. Gunasekera

Harbor Branch Oceanographic Institution

Jose V. Lopez

Harbor Branch Oceanographic Institution, joslo@nova.edu

Peter J. McCarthy

Harbor Branch Oceanographic Institution

Amy E. Wright

Harbor Branch Oceanographic Institution

Find out more information about Nova Southeastern University and the Halmos College of Natural Sciences and Oceanography.

Follow this and additional works at: https://nsuworks.nova.edu/occ_facarticles

Part of the Marine Biology Commons, and the Oceanography and Atmospheric Sciences and Meteorology Commons

\section{Recommended Citation}

Park, Young Chul, Sarath P. Gunasekera, Jose V. Lopez, Peter J. McCarthy, and Amy E. Wright. "Metabolites from the marine-derived fungus Chromocleista sp. isolated from a deep-water sediment sample collected in the Gulf of Mexico." Journal of natural products 69 , no. 4 (2006): 580-584.

This Article is brought to you for free and open access by the Department of Marine and Environmental Sciences at NSUWorks. It has been accepted for inclusion in Marine \& Environmental Sciences Faculty Articles by an authorized administrator of NSUWorks. For more information, please contact nsuworks@nova.edu. 


\title{
Metabolites from the Marine-Derived Fungus Chromocleista sp. Isolated from a Deep-Water Sediment Sample Collected in the Gulf of Mexico
}

\author{
Young Chul Park, Sarath P. Gunasekera,* Jose V. Lopez, Peter J. McCarthy, and Amy E. Wright \\ Division of Biomedical Marine Research, Harbor Branch Oceanographic Institution, 5600 U.S. 1 North, Fort Pierce, Florida 34946
}

Received October 24, 2005

As part of our ongoing chemical investigation of biologically active metabolites from marine fungi, three new compounds, p-hydroxyphenopyrrozin (1) and diketopiperazines $(\mathbf{3}, \mathbf{4})$, have been isolated from the marine-derived fungus Chromocleista sp. In addition, the fungus gave the known compound phenopyrrozin (2), four known diketopiperazines $(\mathbf{6}-\mathbf{9}), N$-acetyltryptamine (10), and agathic acid (11). Another new diketopiperazine (5) was separated and identified as a decomposition product of $\mathbf{3}$ and $\mathbf{4}$. The structures of the new metabolites were determined on the basis of mass spectroscopy, NMR experiments, and derivatization methods. The absolute configuration of $\mathbf{1}$ was determined by X-ray crystallography studies.

The chemical diversity of secondary metabolites reported to date has shown that marine microbes are an excellent resource for the discovery of potential new drugs. ${ }^{1,2}$ Furthermore, marine-derived fungi have been shown to be a potential source for secondary metabolites with interesting bioactivities. ${ }^{3,4}$ In our continuing search for new metabolites from marine-derived fungi, we have isolated a new $7 \mathrm{a}(S)$-p-hydroxyphenopyrrozin (1) and two new diketopiperazines $(\mathbf{3}, \mathbf{4})$ along with their diketopiperazine decomposition product (5) from the cultured fungus Chromocleista sp. isolated from a marine sediment sample collected at a depth of $70 \mathrm{~m}$ in the Gulf of Mexico. In addition, the same fungus yielded the known compounds phenopyrrozine $(2),{ }^{5}$ a radical scavenger, ${ }^{6}$ cyclo(L-Pro-

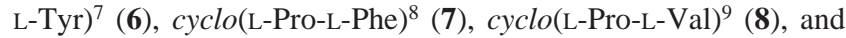
cyclo(L-Pro-D-Leu) ${ }^{10}(\mathbf{9}), N_{\mathrm{b}}$-acetyltryptamine $(\mathbf{1 0}),{ }^{11}$ and agathic acid (11). ${ }^{12,13}$ The structures of all of the known compounds have been confirmed by comparison with spectroscopic data reported in the literature.

\section{Results and Discussion}

In this paper, we report the isolation and structure elucidation of new compounds $\mathbf{1}, \mathbf{3}, \mathbf{4}$, and $\mathbf{5}$. The fungal cell mass and added resin were extracted with a mixture of $\mathrm{CH}_{2} \mathrm{Cl}_{2} / \mathrm{MeOH}$ (1:1) to give a crude extract. The EtOAc-soluble fraction of the crude extract was subjected to silica gel column chromatography using a heptane/ $\mathrm{EtOAc} / \mathrm{MeOH}(80: 20: 0 \rightarrow$ 0:0:100) gradient to give seven fractions. Further chromatography of the second fraction gave nine subfractions. Repeated chromatography of these subfractions gave compounds 1-4 and 6-11. Compound 5 was isolated as a decomposition product of compounds $\mathbf{3}$ and $\mathbf{4}$.

Crystallization of compound $\mathbf{1}$ in $\mathrm{MeOH}$ furnished colorless crystals, $\mathrm{mp} 231-233{ }^{\circ} \mathrm{C}$ and specific rotation $[\alpha]^{25} \mathrm{D}+34.0(c 0.34$, $\mathrm{MeOH})$. High-resolution FABMS of $\mathbf{1}$ revealed a molecular ion peak at $\mathrm{m} / z, 232.0979$ for $\mathrm{M}+\mathrm{H}^{+}$corresponding with the molecular formula $\mathrm{C}_{13} \mathrm{H}_{13} \mathrm{NO}_{3}$ and eight degrees of unsaturation. IR spectral absorptions at 1676 and $3188 \mathrm{~cm}^{-1}$ indicated the presence of a conjugated carbonyl group and hydroxyl functionality. The ${ }^{13} \mathrm{C}$ and DEPT NMR spectra revealed the presence of three methylene carbons $\left(\delta_{\mathrm{C}} 42.9,32.0\right.$, and 29.3), two aromatic methine carbons each accounting for two carbon atoms $\left(\delta_{\mathrm{C}} 129.4,116.3\right)$, one phenolic carbon $\left(\delta_{\mathrm{C}} 158.3\right)$, one aliphatic methine $\left(\delta_{\mathrm{C}} 63.7\right)$, three quaternary olefinic carbons $\left(\delta_{\mathrm{C}} 141.9,127.4\right.$, and 125.6), and a carbonyl carbon $\left(\delta_{\mathrm{C}} 173.7\right)$. The ${ }^{1} \mathrm{H}$ NMR spectrum revealed signals for seven protons observed at $\delta 4.35(1 \mathrm{H}, \mathrm{dd}, J=10.5,5.7 \mathrm{~Hz}$,

* To whom correspondence should be addressed. Tel: 772-465-2400. Fax: 772-461-2221. E-mail: sgunaseker@hboi.edu.

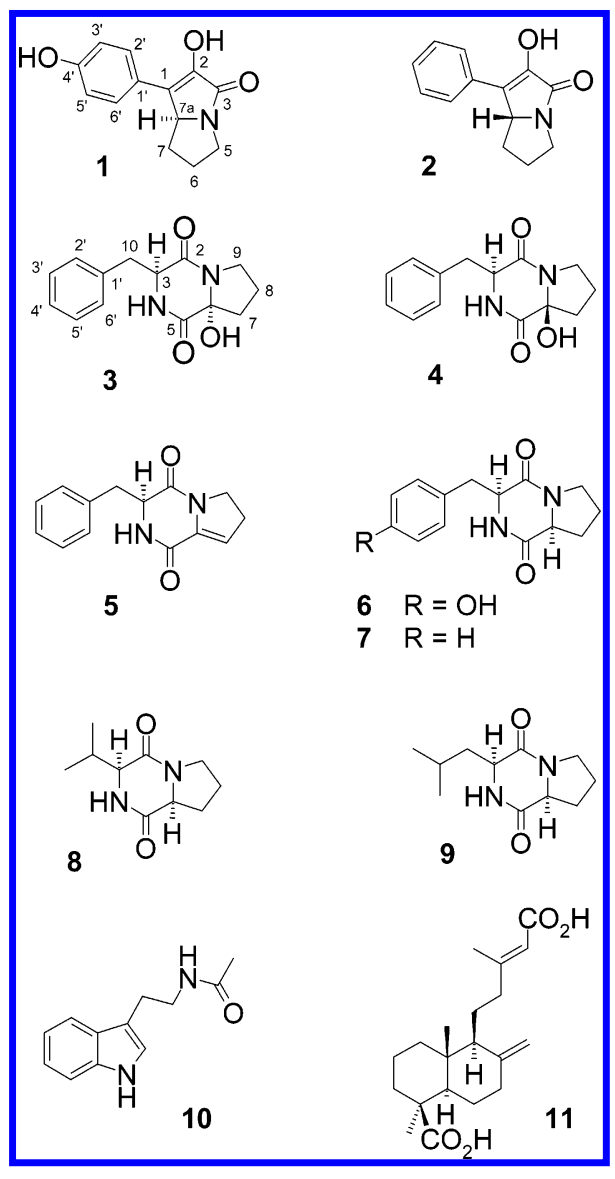

H-7a), 3.34 (1H, m, H-5 $\beta$ ), 3.24 (1H, m, H-5 $\alpha$ ), 2.29 (1H, m, H-7 $\beta$ ), $2.22(2 \mathrm{H}, \mathrm{m}, \mathrm{H}-6)$, and $1.13(1 \mathrm{H}, \mathrm{m}, \mathrm{H}-7 \alpha)$. The COSY spectrum displayed the correlations for geminal couplings in $\mathrm{H}_{2}-5, \mathrm{H}_{2}-6$, and $\mathrm{H}_{2}-7$ and correlations between $\mathrm{H}_{2}-5$ and $\mathrm{H}_{2}-6, \mathrm{H}_{2}-6$, and $\mathrm{H}_{2}-7$, indicating consecutive methylene connectivities. The second set of proton signals at $\delta 7.52\left(2 \mathrm{H}, \mathrm{dd}, J=8.5 \mathrm{~Hz}, \mathrm{H}-2^{\prime}\right.$ and $\left.\mathrm{H}-6^{\prime}\right)$ and $6.75\left(2 \mathrm{H}, \mathrm{dd}, J=8.5 \mathrm{~Hz}, \mathrm{H}-3^{\prime}\right.$ and $\left.\mathrm{H}-5^{\prime}\right)$ indicated the presence of a para-substituted benzene ring. HMBC correlations from $\delta_{\mathrm{H}} 3.24$ $(\mathrm{H}-5 \alpha)$ and $\delta_{\mathrm{H}} 3.34(\mathrm{H}-5 \beta)$ to $\mathrm{C}-3, \mathrm{C}-6, \mathrm{C}-7$, and C-7a determined the position of the carbonyl group. Additional HMBC correlations revealed connectivities from the methine signal at $\delta_{\mathrm{H}} 4.35(\mathrm{H}-7 \mathrm{a})$ to $\mathrm{C}-1, \mathrm{C}-2, \mathrm{C}-3, \mathrm{C}-6$, and C-7. The combination of the above data established a bicyclic system in the molecular structure. The HMBC correlations from $\delta_{\mathrm{H}} 7.52\left(\mathrm{H}-2^{\prime}\right.$ and $\left.\mathrm{H}-6^{\prime}\right)$ to $\mathrm{C}-1$ and $\mathrm{C}-4^{\prime}$ connected 


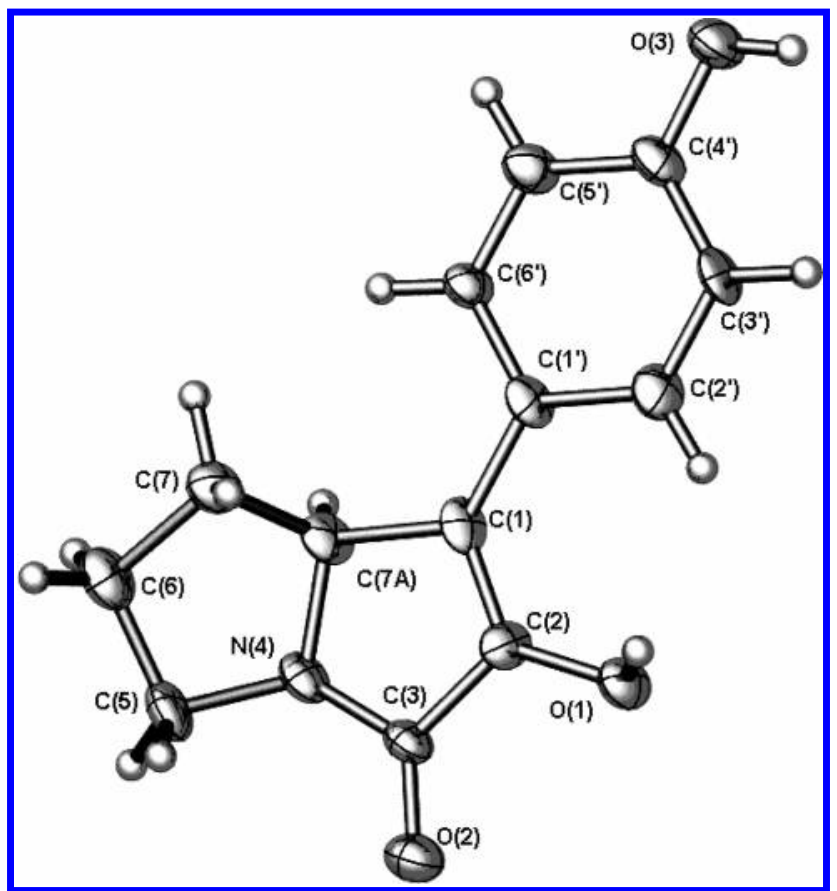

Figure 1. Computer-generated perspective drawing of the X-ray model of compound $\mathbf{1}$.

the $p$-hydroxyphenyl group to the bicyclic system. To determine the absolute stereochemistry at the chiral center $7 \mathrm{a}$, this compound was crystallized for X-ray studies. The structure of compound $\mathbf{1}$ was confirmed as 5,6,7,7a $(S)$-tetrahydro-2-hydroxy-1-( $p$-hydroxyphenyl)-3H-pyrrolizin-3-one (Figure 1 ) by single-crystal X-ray diffraction. ${ }^{14}$

Comparison of the NMR and mass spectroscopic data of $\mathbf{2}$ with those of compound $\mathbf{1}$ and with literature reported data $\mathrm{a}^{5,6}$ identified compound $\mathbf{2}$ as 5,6,7,7a-tetrahydro-2-hydroxy-1-phenyl-3H-pyrrolizin-3-one. This compound was previously isolated from a Penicillium sp., and its absolute configuration at $7 \mathrm{a}$ was not reported in these publications. The specific rotation value of $[\alpha]^{25}-10.2$ reported for this known compound ${ }^{5}$ and a similar specific rotation value of $[\alpha]^{25}-13.7$ observed for compound 2 suggested the same $7 \mathrm{a}$-chiral center for both isolates. The positive specific rotation value of $[\alpha]^{25} \mathrm{D}+34.0$ observed for $\mathbf{1}$ with $7 \mathrm{a}(S)$ configuration thus suggested an opposite $7 \mathrm{a}(R)$ configuration for $\mathbf{2}$, and therefore, the structure of $\mathbf{2}$ was confirmed as 5,6,7,7a(R)-tetrahydro-2-hydroxy1-phenyl-3H-pyrrolizin-3-one.

Compounds $\mathbf{3}$ and $\mathbf{4}$ were identified as two new diketopiperazine epimers that bear a hydroxyl group at the quaternary carbon atom (C-6) of the proline residues. High-resolution FABMS of 3 supported the molecular formula $\mathrm{C}_{14} \mathrm{H}_{16} \mathrm{~N}_{2} \mathrm{O}_{3}(\mathrm{~m} / z, 243.1197[\mathrm{M}+$ $\left.\mathrm{H}-\mathrm{H}_{2} \mathrm{O}\right]^{+}$), and low-resolution ESIMS of 4 supported the molecular formula $\mathrm{C}_{14} \mathrm{H}_{16} \mathrm{~N}_{2} \mathrm{O}_{3}\left(\mathrm{~m} / \mathrm{z}, 261.2[\mathrm{M}+\mathrm{H}]^{+}\right)$. Both compounds 3 and $\mathbf{4}$ displayed the typical ${ }^{13} \mathrm{C}$ NMR chemical shift values observed for a diketopiperazine ring system, which included the characteristic amide groups at C-2 $\left(\delta_{\mathrm{C}} 168.1\right.$ and 167.7) and C-5 $\left(\delta_{\mathrm{C}} 166.1\right.$ and 165.6), methine residue at C-3 $\left(\delta_{\mathrm{C}} 55.8\right.$ and $59.3)$, and aliphatic quaternary carbon at C-6 $\left(\delta_{\mathrm{C}} 87.6\right.$ and 86.5$)$, respectively. The ${ }^{13} \mathrm{C}$ chemical shift values for $\mathrm{C}-6$ in $\mathbf{3}\left(\delta_{\mathrm{C}} 87.6\right)$ and in $4\left(\delta_{\mathrm{C}} 86.5\right)$ suggested the presence of a hydroxyl group attached to this position. The COSY spectra of $\mathbf{3}$ and $\mathbf{4}$ indicated the presence of three consecutive methylene groups characteristic of a proline residue in both compounds. Similarly, the presence of five aromatic protons and a benzylic group in both compounds (see Table 1) indicated the presence of a phenylalanine residue. The HMBC spectrum showed correlations between $\mathrm{H}_{2}-7$ of the proline residue and the remaining methylene carbons C-8 and C-9 of the proline residue and to $\mathrm{C}-6(\delta 87.6$ in $\mathbf{3}$ and 86.5 in $\mathbf{4})$ and $\mathrm{C}-5(\delta$ 166.1 in 3 and 165.6 in 4). Similarly, the HMBC spectrum showed correlation between $\mathrm{H}_{2}-8$ and C-6, C-7, and C-9. Combination of these data assigned the hydroxyl group to position $\mathrm{C}-6$ of the proline moiety. The HMBC correlations between $\mathrm{H}-3$ ( $\delta 4.25$ in $\mathbf{3}$ and 4.21 in 4) and C-2, C-5, C-10, and C-1' and other correlations described above established a phenylalanine-proline diketopiperazine molecular structures for $\mathbf{3}$ and $\mathbf{4}$. The absolute configuration of C-3 of the phenylalanine residue in compound $\mathbf{3}$ was determined by Marfey's method. ${ }^{15}$ HPLC analysis of the FDAA derivative of $\mathbf{3}$ gave the same retention time as the derivative prepared from an authentic (L)-phenylalanine, and therefore, the L configuration was assigned to the phenylalanine residue. Compounds $\mathbf{3}$ and $\mathbf{4}$ when stored separately in $\mathrm{CDCl}_{3}$ at room temperature gradually decomposed to give compound 5. The high-resolution FABMS of $\mathbf{5}$ revealed a molecular ion peak at $m / z 243.0832\left([\mathrm{M}+\mathrm{H}]^{+}\right)$, supporting the molecular formula $\mathrm{C}_{14} \mathrm{H}_{14} \mathrm{~N}_{2} \mathrm{O}_{2}$ with nine degrees of unsaturation, and indicated a difference in elements $\mathrm{H}_{2} \mathrm{O}(18$ amu) from 3 and 4. Analysis of the ${ }^{1} \mathrm{H},{ }^{13} \mathrm{C}$, and HMQC NMR spectra of $\mathbf{5}$ showed the presence of two amide carbonyl carbons $\left(\delta_{\mathrm{C}} 161.7\right.$ and 157.1), two olefinic carbons $\left(\delta_{\mathrm{C}} 132.6, \mathrm{C}\right.$ and 119.1 , $\mathrm{CH})$ and six aromatic carbons $\left(\delta_{\mathrm{C}-1^{\prime}} 135.0, \delta_{\mathrm{C}-2^{\prime}, 6^{\prime}} 129.6, \delta_{\mathrm{C}-3^{\prime}, 5^{\prime}}\right.$ 129.0 , and $\delta_{\mathrm{C}-4^{\prime}}$ 127.6). These data together with three ring systems accounted for all nine degrees of unsaturation in the molecule. Comparison of ${ }^{1} \mathrm{H}$ NMR spectra of $\mathbf{3}$ and $\mathbf{5}$ indicated the expected close similarities and that the $\mathrm{C}-6$ methylene group $(\delta 1.93,2.31)$ in 3 has been substituted by a new olefinic signal appearing at $\delta$ 6.15. Similarly, the ${ }^{13} \mathrm{C}$ spectrum of $\mathbf{5}$ showed the presence of two new olefinic signals instead of C-6 hydroxyl and C-7 methylene carbons present in compounds $\mathbf{3}$ and $\mathbf{4}$. The HMBC correlations between the newly formed olefinic proton at $\delta 6.15(1 \mathrm{H}, \mathrm{t}, J=2.8$ $\mathrm{Hz}, \mathrm{H}-7)$ and C-6 olefinic carbon $(\delta 132.7, \mathrm{C}), \mathrm{C}-5$ amide carbon $(\delta$ 157.1, $\mathrm{C}=\mathrm{O}), \mathrm{C}-8(\delta 27.8)$ methylene carbon, and $\mathrm{C}-9(\delta$ 45.4) methylene carbon established the position of the double bond in the proline residue. These data established the structure of diketopiperazine $\mathbf{5}$ as cyclo(6,7-en-Pro-L-Phe) and the structures of diketopiperazines $\mathbf{3}$ and $\mathbf{4}$ as C-6 epimers of cyclo(6-Hyp-L-Phe).

The absolute configuration at C-6 in compounds $\mathbf{3}$ and $\mathbf{4}$ was not determined by Marfey's method because the hydroxyproline residue decomposed under acidic conditions. Therefore, the stereochemistry at C-6 of compounds $\mathbf{3}$ and $\mathbf{4}$ was determined on the basis of proton-proton coupling constants observed between the $\mathrm{C}-3$ methine proton and nonequivalent $\mathrm{C}-10$ benzylic protons in the phenylalanine residue. The use of coupling constants to determine the stereochemistry in similar ABX type systems in diketopiperazines is described in the literature. ${ }^{16-21}$ The protonproton coupling constants of $\mathrm{H}-3$ and benzylic $\mathrm{H}-10 \mathrm{a}$ and $\mathrm{H}-10 \mathrm{~b}$ of compound $3\left(\delta 4.25_{\mathrm{H}-3}\left({ }^{3} J_{\mathrm{H}-3 / \mathrm{H}-10 \mathrm{a}}=9.9 \mathrm{~Hz}\right.\right.$ and ${ }^{3} J_{\mathrm{H}-3 / \mathrm{H}-10 \mathrm{~b}}=$ $3.6 \mathrm{~Hz}), 2.73_{\mathrm{H}-10 \mathrm{a}}\left({ }^{2} J_{\mathrm{H}-10 \mathrm{a} / \mathrm{H}-10 \mathrm{~b}}=14.3 \mathrm{~Hz}\right.$ and ${ }^{3} J_{\mathrm{H}-10 \mathrm{a} / \mathrm{H}-3}=9.9$ $\mathrm{Hz})$, and $3.62_{\mathrm{H}-10 \mathrm{~b}}\left({ }^{2} J_{\mathrm{H}-10 \mathrm{~b} / \mathrm{H}-10 \mathrm{a}}=14.3 \mathrm{~Hz}\right.$ and ${ }^{3} J_{\mathrm{H}-10 \mathrm{~b} / \mathrm{H}-3}=3.6$ $\mathrm{Hz}$ )) indicated a dihedral angle of $180^{\circ}$ (trans) for $\mathrm{H}^{3}-\mathrm{C}-\mathrm{C}-\mathrm{H}^{10 a}$ and a dihedral angle of $69^{\circ}$ (gauche) for $\mathrm{H}^{3}-\mathrm{C}-\mathrm{CH}^{10 \mathrm{~b}}$ (Figure 2). These coupling constant values are in agreement with the known cyclo(L-Pro-L-Phe) reported in the literature. ${ }^{16}$ In contrast, the proton-proton coupling constants of $\mathrm{H}-3$ and benzylic $\mathrm{H}-10$ of compound $4\left(\delta 4.21_{\mathrm{H}-3}\left({ }^{3} J_{\mathrm{H}-3 / \mathrm{H}-10 \mathrm{a}}=4.0 \mathrm{~Hz}\right.\right.$ and ${ }^{3} J_{\mathrm{H}-3 / \mathrm{H}-10 \mathrm{~b}}=$ $8.1 \mathrm{~Hz}), 3.17_{\mathrm{H}-10 \mathrm{a}}\left({ }^{2} J_{\mathrm{H}-10 \mathrm{a} / \mathrm{H}-10 \mathrm{~b}}=13.6 \mathrm{~Hz}\right.$ and ${ }^{3} J_{\mathrm{H}-10 \mathrm{a} / \mathrm{H}-3}=4.0$ $\mathrm{Hz})$, and $3.27_{\mathrm{H}-10 \mathrm{~b}}\left({ }^{2} J_{\mathrm{H}-10 \mathrm{~b} / \mathrm{H}-10 \mathrm{a}}=13.6 \mathrm{~Hz}\right.$ and ${ }^{3} J_{\mathrm{H}-10 \mathrm{~b} / \mathrm{H}-3}=8.1$ $\mathrm{Hz})$ ) indicated a dihedral angles of $50^{\circ}$ (gauche) for $\mathrm{H}^{3}-\mathrm{C}-\mathrm{C}-$ $\mathrm{H}^{10 \mathrm{a}}$ and a dihedral angle of $166^{\circ}$ (trans) for $\mathrm{H}^{3}-\mathrm{C}-\mathrm{C}-\mathrm{H} .{ }^{10 \mathrm{~b}}$ Similarly, these coupling constants are in agreement with the known cyclo(D-Pro-L-Phe) reported in the literature. ${ }^{17}$ These data confirmed the structures of diketopiperazines $\mathbf{3}$ and $\mathbf{4}$ as cyclo(D-6-Hyp-LPhe) and cyclo(L-6-Hyp-L-Phe), respectively. Related diketopiperazines with a (L)-trans-4-Hyp residue and a (D)-cis-4-Hyp residue have been reported from the marine sponge of the family Jaspidae ${ }^{16}$ and the marine yeast Aureobasidium pullulans, ${ }^{17}$ respectively.

The four new compounds were screened for their bioactivity against the bacterium Staphylococcus aureus and the fungus 
Table 1. NMR Spectral Data of $\mathbf{3}-\mathbf{5}$ in $\mathrm{CDCl}_{3}\left({ }^{1} \mathrm{H}, 500 \mathrm{MHz} ;{ }^{13} \mathrm{C}, 125 \mathrm{MHz}\right)$

\begin{tabular}{|c|c|c|c|c|c|c|}
\hline \multirow[b]{2}{*}{ position } & \multicolumn{2}{|c|}{3} & \multicolumn{2}{|c|}{4} & \multicolumn{2}{|c|}{5} \\
\hline & $\delta_{\mathrm{H}}($ mult; $J$ in $\mathrm{Hz})$ & $\delta_{\mathrm{C}}$ & $\delta_{\mathrm{H}}(\mathrm{mult} ; J$ in $\mathrm{Hz})$ & $\delta_{\mathrm{C}}$ & $\delta_{\mathrm{H}}(\mathrm{mult} ; J$ in $\mathrm{Hz})$ & $\delta_{\mathrm{C}}$ \\
\hline \multirow[t]{2}{*}{2} & & $168.1(\mathrm{C})$ & & $167.7(\mathrm{C})$ & & $161.7(\mathrm{C})$ \\
\hline & $4.25(\mathrm{dd}, 9.9,3.6)$ & $55.8(\mathrm{CH})$ & $4.21(\mathrm{dd}, 8.1,4.0)$ & $59.3(\mathrm{CH})$ & $4.34(\mathrm{dd}, 8.7,4.0)$ & $58.5(\mathrm{CH})$ \\
\hline $\mathrm{NH}$ & $5.78(\mathrm{~s})$ & & $6.17(\mathrm{~s})$ & & $5.89(\mathrm{~s})$ & \\
\hline 5 & & $166.1(\mathrm{C})$ & & $165.6(\mathrm{C})$ & & $157.1(\mathrm{C})$ \\
\hline 6 & & $87.6(\mathrm{C})$ & & $86.5(\mathrm{C})$ & & 132.7 (C) \\
\hline \multirow[t]{2}{*}{7} & $1.93(\mathrm{~m})$ & $36.8\left(\mathrm{CH}_{2}\right)$ & $1.98(\mathrm{~m})$ & $36.8\left(\mathrm{CH}_{2}\right)$ & $6.15(\mathrm{t}, 2.8)$ & $119.1(\mathrm{CH})$ \\
\hline & $2.31(\mathrm{~m})$ & & $2.22(\mathrm{~m})$ & & & \\
\hline \multirow[t]{2}{*}{8} & $1.86(\mathrm{~m})$ & $19.9\left(\mathrm{CH}_{2}\right)$ & $1.94(\mathrm{~m})$ & $19.1\left(\mathrm{CH}_{2}\right)$ & $2.67(\mathrm{~m})$ & $27.8\left(\mathrm{CH}_{2}\right)$ \\
\hline & $3.64(\mathrm{~m})$ & $45.4\left(\mathrm{CH}_{2}\right)$ & $3.66(\mathrm{~m})$ & $45.3\left(\mathrm{CH}_{2}\right)$ & $3.96(\mathrm{~m})$ & $45.4\left(\mathrm{CH}_{2}\right)$ \\
\hline \multirow[t]{2}{*}{10} & $2.73(\mathrm{dd}, 14.3,9.9)$ & $41.0\left(\mathrm{CH}_{2}\right)$ & $3.17(\mathrm{dd}, 13.6,4.0)$ & $41.0\left(\mathrm{CH}_{2}\right)$ & $2.98(\mathrm{dd}, 13.7,8.7)$ & $41.2\left(\mathrm{CH}_{2}\right)$ \\
\hline & $3.62(\mathrm{dd}, 14.3,3.6)$ & & $3.27(\mathrm{dd}, 13.6,8.1)$ & & $3.34(\mathrm{dd}, 13.6,4.0)$ & \\
\hline $1^{\prime}$ & & $135.7(\mathrm{C})$ & & $135.7(\mathrm{C})$ & & $135.7(\mathrm{C})$ \\
\hline 2 & $7.23(\mathrm{~d}, 7.3)$ & $129.3(\mathrm{CH})$ & $7.23(\mathrm{~d}, 7.3)$ & $129.8(\mathrm{CH})$ & $7.18(\mathrm{~d}, 7.3)$ & $129.6(\mathrm{CH})$ \\
\hline $3^{\prime}$ & $7.35(\mathrm{t}, 7.3)$ & $129.2(\mathrm{CH})$ & $7.35(\mathrm{t}, 7.3)$ & $129.2(\mathrm{CH})$ & $7.31(\mathrm{t}, 7.3)$ & $129.0(\mathrm{CH})$ \\
\hline $4^{\prime}$ & $7.29(\mathrm{t}, 7.3)$ & $127.6(\mathrm{CH})$ & $7.29(\mathrm{t}, 7.3)$ & $127.6(\mathrm{CH})$ & $7.26(t, 7.3)$ & $127.6(\mathrm{CH})$ \\
\hline $5^{\prime}$ & $7.35(\mathrm{t}, 7.3)$ & $129.2(\mathrm{CH})$ & $7.35(\mathrm{t}, 7.3)$ & $129.2(\mathrm{CH})$ & $7.31(\mathrm{t}, 7.3)$ & $129.0(\mathrm{CH})$ \\
\hline $6^{\prime}$ & $7.23(\mathrm{~d}, 7.3)$ & $129.3(\mathrm{CH})$ & $7.23(\mathrm{~d}, 7.3)$ & $129.8(\mathrm{CH})$ & $7.18(\mathrm{~d}, 7.3)$ & $129.6(\mathrm{CH})$ \\
\hline
\end{tabular}

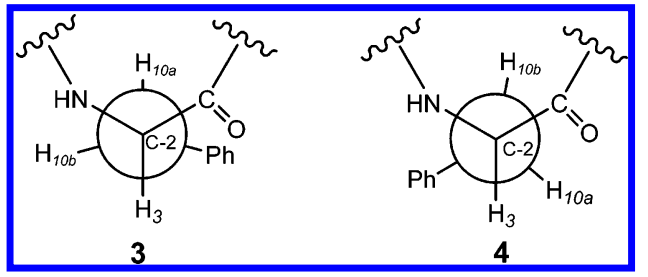

Figure 2. Proposed conformation models of the C-3-C-10 bond in compounds $\mathbf{3}$ and $\mathbf{4}$.

Candida albicans. Compound $\mathbf{1}$ showed a minimum inhibition concentration of $25 \mu \mathrm{g} / \mathrm{mL}$ against $C$. albicans. Compounds 3-5 showed no activity at concentrations up to $50 \mu \mathrm{g} / \mathrm{mL}$. None of the compounds showed activity against $S$. aureus when tested at 50 $\mu \mathrm{g} / \mathrm{mL}$. The cytoxicity of these compounds was evaluated against a panel of cancer cell lines: P388 murine leukemia, A549 human lung adenocarcinoma, PANC-1 human pancreatic cancer, and NCIADR-RES tumor cells. All new compounds failed to register any cytotoxicity at a concentration of $5 \mu \mathrm{g} / \mathrm{mL}$.

\section{Experimental Section}

General Experimental Procedures. The melting point measured with a Gallenkamp melting point apparatus is uncorrected. Optical rotations were recorded on a Jasco DIP-370 digital polarimeter. UV spectra were measured with a Hitachi U-3010 spectrophotometer. IR spectra were obtained on a Midac M-1200 with Galactic GRAMS/386 software. 1D and 2D NMR spectra were measured on a Bruker AMX500 instrument. The ${ }^{1} \mathrm{H}$ NMR chemical shifts (referenced to $\mathrm{CDCl}_{3}$ observed at $\delta$ 7.24) were assigned using a combination of data from COSY and HMQC experiments. Similarly, ${ }^{13} \mathrm{C}$ NMR chemical shifts (referenced to $\mathrm{CDCl}_{3}$ observed at $\delta 77.0$ and $\mathrm{CD}_{3} \mathrm{OD}$ observed at $\delta$ 49.0) were assigned on the basis of DEPT and HMQC experiments. Low-resolution mass spectra ESI-MS were obtained on a Finnigan LTQ LC-MS with an electrospray ionization detector. The HRMS were obtained on a Finnigan MAT95Q mass spectrometer at the Spectroscopic Services Group, University of Florida, Gainesville, FL.

Isolation and Cultivation of Fungal Strain R721. The fungal strain R721 was isolated from a sediment sample collected on August 17, 2001, by a manned submersible (Clelia) at a depth of $70 \mathrm{~m}$, from the Gulf of Mexico (latitude $26^{\circ} 15.87^{\prime} \mathrm{N}$; longitude $83^{\circ} 42.40^{\prime} \mathrm{W}$ ). The fungus was isolated using solid agar methods with starch casein medium consisting of the following: $10 \mathrm{~g}$ of starch, $1 \mathrm{~g}$ of casein, $1 \mathrm{~mL}$ of trace metal solution, ${ }^{22} 15 \mathrm{~g}$ of agar, $750 \mathrm{~mL}$ of artificial seawater, and $250 \mathrm{~mL}$ of deionized water. R721 was identified by partial sequence analysis of the $28 \mathrm{~S}$ large subunit rRNA gene using LROR and LR7 primers derived from the R. Vilgalys laboratory. A close taxonomic relationship likely exists between the two fungal genera Chromocleista and Penicillium, since both belong in the family Trichocomaceae, order Eurotiales. Although our 28S rRNA analysis gives only limited identification for fungal isolate R721, full taxonomic identification of this strain goes beyond the scope of this paper (http://www.biology.duke.edu/fungi/mycolab/primers.htm), followed by BLAST queries against GenBank, which resulted in a closest match to $C$. malacheita $(97 \%)$. The fungus is maintained on Emerson's YpSs agar prepared with $75 \%$ artificial seawater and has been deposited into the Harbor Branch Marine Microbial Culture Collection. For chemical investigation the strain was cultured for 7 days in SYZ broth (15 g of soluble starch, $2 \mathrm{~g}$ of yeast extract, $4 \mathrm{~g}$ of NZ-amine, $2 \mathrm{~g}$ of dextrose, $4 \mathrm{~g}$ (dry weight) of Amberlite XAD16 resin, $750 \mathrm{~mL}$ of artificial seawater, $250 \mathrm{~mL}$ of deionized water) at $25{ }^{\circ} \mathrm{C}$ and $210 \mathrm{rpm}$ as $4 \times 1 \mathrm{~L}$ batches in triplebaffled Fernbach flasks. The cell mass and resin were collected by centrifugation $(8500 \mathrm{~g}, 15 \mathrm{~min})$.

Extraction and Isolation. The cultured fungal cell mass and Amberlite XAD-16 resin were filtered and then extracted five times with $50 \% \mathrm{CH}_{2} \mathrm{Cl}_{2} / \mathrm{MeOH}(1 \mathrm{~L})$. The organic extracts were combined and dried over anhydrous $\mathrm{MgSO}_{4}$ and concentrated in vacuo to afford a dark brown extract $(7.3 \mathrm{~g})$. The extract was partitioned five times with $70 \% \mathrm{EtOAc} / \mathrm{H}_{2} \mathrm{O}(1 \mathrm{~L})$. The organic layer was dried with anhydrous $\mathrm{MgSO}_{4}$ and concentrated in vacuo to yield $1.35 \mathrm{~g}$ of an EtOAc-soluble fraction. The EtOAc-soluble fraction was chromatographed on a column of $\mathrm{SiO}_{2}$ gel using a heptane/EtOAc/MeOH (80:20:0 $\rightarrow$ 0:0:100) step gradient system to give seven fractions. The second fraction (248.6 $\mathrm{mg}$ ), eluted with heptane/EtOAc/MeOH (60:40:0), was rechromatographed on a column of $\mathrm{SiO}_{2}$ gel using a heptane/EtOAc/MeOH (50: 50:0 $\rightarrow$ 0:95:5) step gradient system to provide nine subfractions. The combined fractions 7 and $8(83.8 \mathrm{mg})$ eluted with EtOAc/MeOH (95: 5) were further subjected to normal-phase Sep-Pack silica cartridge (Waters Corp., Milford, MA) separation with $3 \% \mathrm{MeOH} / \mathrm{CH}_{2} \mathrm{Cl}_{2}$ to yield 5,6,7,7a $(S)$-tetrahydro-2-hydroxy-1-( $p$-hydroxyphenyl)-3H-pyrrolizin-3-one (1) as a white solid (52 $\mathrm{mg}, 0.7 \%$ of crude extract wt) and 5,6,7,7a(S)-tetrahydro-2-hydroxy-1-phenyl-3 $\mathrm{H}$-pyrrolizin-3-one (2) as a white solid (14 mg, $0.2 \%$ of crude extract). The third fraction (142.1 mg) was rechromatographed on a column of silica gel with a heptane/EtOAc/MeOH (30:70:0 $\rightarrow$ 0:90:10) gradient system to provide six subfractions. These subfractions on further purification by HPLC $\left(\mathrm{SiO}_{2}, 5 \mu \mathrm{m}, 250 \times 10 \mathrm{~mm}\right)$ with $3 \% \mathrm{MeOH} / \mathrm{CH}_{2} \mathrm{Cl}_{2}$ gave cyclo(L-6Hyp-L-Phe) (3) as a white solid $(0.8 \mathrm{mg}, 0.01 \%$ of crude extract), cyclo(D-6-Hyp-L-Phe) (4) as a white solid $(1.8 \mathrm{mg}, 0.02 \%$ of crude extract), and compounds $\mathbf{6}-\mathbf{1 1}$. Compounds 3 and 4 in $\mathrm{CDCl}_{3}$ on leaving at room temperature in the NMR tube gradually decomposed to give cyclo(6,7-en-Pro-L-Phe) (5) as a pure compound.

$5,6,7,7 \mathrm{a}(S)$-Tetrahydro-2-hydroxy-1-( $p$-hydroxyphenyl)-3H-pyrrolizin-3-one (1): $[\alpha]^{25}{ }_{\mathrm{D}}+34.0(c 0.34, \mathrm{MeOH})$; UV $(\mathrm{MeOH}) \lambda_{\max }$ $(\log \epsilon) 198$ (4.5), 222 (1.3), $307(1.8) \mathrm{nm}$; IR (KBr) $v_{\max }$ 3188, 1676, $1519,1427,1361 \mathrm{~cm}^{-1} ;{ }^{1} \mathrm{H}$ NMR $\left(\mathrm{CD}_{3} \mathrm{OD}, 500 \mathrm{MHz}\right) \delta 7.52(2 \mathrm{H}, \mathrm{d}$, $J=8.5 \mathrm{~Hz}, \mathrm{H}-2^{\prime}$ and $\left.\mathrm{H}-6^{\prime}\right), 6.75\left(2 \mathrm{H}, \mathrm{d}, J=8.5 \mathrm{~Hz}, \mathrm{H}-3^{\prime}\right.$ and $\left.\mathrm{H}-5^{\prime}\right)$, $4.35(1 \mathrm{H}, \mathrm{dd}, J=10.5,5.7 \mathrm{~Hz}, \mathrm{H}-7 \mathrm{a}), 3.34(1 \mathrm{H}, \mathrm{m}, \mathrm{H}-5 \beta), 3.24(1 \mathrm{H}$, m, H-5 $\alpha$ ), 2.29 (1H, m, H-7 $\beta$ ), 2.22 (2H, m, H-6), 1.13 (1H, m, H-7 $\alpha$ ); ${ }^{13} \mathrm{C}$ NMR $\left(\mathrm{CD}_{3} \mathrm{OD}, 125 \mathrm{MHz}\right) \delta 173.7$ (C, C-3), 158.3 (C, C-4'), 141.9 (C, C-2), 129.4 (CH, C-2' and C-6'), 127.4 (C, C-1), 125.6 (C, C-1'), $116.3\left(\mathrm{CH}, \mathrm{C}-3^{\prime}\right.$ and $\left.\mathrm{C}-5^{\prime}\right), 63.7(\mathrm{CH}, \mathrm{C}-7 \mathrm{a}), 42.9\left(\mathrm{CH}_{2}, \mathrm{C}-5\right), 32.0$ 
$\left(\mathrm{CH}_{2}, \mathrm{C}-7\right), 29.3\left(\mathrm{CH}_{2}, \mathrm{C}-6\right)$; LRESIMS (positive ion) $\mathrm{m} / z$ 232.2 [M $+\mathrm{H}]^{+}$; HRFABMS m/z $232.0979[\mathrm{M}+\mathrm{H}]^{+}$(calcd for $\mathrm{C}_{13} \mathrm{H}_{14} \mathrm{NO}_{3}$, 232.0973).

cyclo(D-6-Hyp-L-Phe) (3): $[\alpha]^{25} \mathrm{D}-26.1$ (c $\left.0.03, \mathrm{MeOH}\right) ; \mathrm{UV}$ $(\mathrm{MeOH}) \lambda_{\max }(\log \epsilon) 198$ (3.5), 257 (0.3) nm; LRESIMS (positive ion) $m / z, 261.2[\mathrm{M}+\mathrm{H}]^{+}$; HRFABMS (positive ion) $m / z$ 243.1197 [M + H $\left.-\mathrm{H}_{2} \mathrm{O}\right]^{+}$(calcd for $\mathrm{C}_{14} \mathrm{H}_{15} \mathrm{~N}_{2} \mathrm{O}_{2}, 243.1133$ ).

cyclo(L-6-Hyp-L-Phe) (4): UV (MeOH) $\lambda_{\max }(\log \epsilon) 200$ (3.7), 257 (0.4) nm; LRESIMS (positive ion) $\mathrm{m} / z$ 261.2 $[\mathrm{M}+\mathrm{H}]^{+}, 299.3[\mathrm{M}+$ $\mathrm{K}]^{+}, 283.2[\mathrm{M}+\mathrm{Na}]^{+}$.

cyclo(6,7-en-Pro-L-Phe) (5): $[\alpha]^{25}$ D -31.9 (c 0.05, MeOH); UV $(\mathrm{MeOH}) \lambda_{\max }(\log \epsilon) 200$ (3.7), 257 (0.5), 330 (0.2) nm; LRESIMS (positive ion) $\mathrm{m} / \mathrm{z}$ 243.2 $[\mathrm{M}+\mathrm{H}]^{+}$; HRFABMS (positive ion) $\mathrm{m} / \mathrm{z}$ $243.0832[\mathrm{M}+\mathrm{H}]^{+}$(calcd for $\mathrm{C}_{14} \mathrm{H}_{15} \mathrm{~N}_{2} \mathrm{O}_{2}, 243.1133$ ).

1-Fluoro-2,4-dinitrophenyl-5-L-alaninamide (FDAA, Marfey's reagent) Derivatization and Absolute Stereochemistry. A solution of diketopiperazine $(3,0.15 \mathrm{mg})$ in $6 \mathrm{~N} \mathrm{HCl}(1 \mathrm{~mL})$ was heated at 100 ${ }^{\circ} \mathrm{C}$ for $16 \mathrm{~h}$. The excess $\mathrm{HCl}$ was removed under vacuum. The dry hydrolyzate was placed in a $1 \mathrm{~mL}$ reacti-vial and treated with $1 \%$ solution of FDAA $(200 \mu \mathrm{L})$ in acetone followed by $1.0 \mathrm{M} \mathrm{NaHCO}_{3}$ $(40 \mu \mathrm{L})$. The reaction mixture was heated at $45^{\circ} \mathrm{C}$ for $1.5 \mathrm{~h}$ and cooled. The mixture was acidified with $2.0 \mathrm{M} \mathrm{HCl}(20 \mu \mathrm{L})$. Likewise, standard D- and L-phenylalanine were derivatized separately. The derivatized hydrolyzate and standard amino acids were subjected to HPLC (RP$\mathrm{C}_{18}, 10 \mu \mathrm{m}, 4.6 \mathrm{~mm} \times 250 \mathrm{~mm}$ ) using the following gradient program. Solvent A: $\mathrm{H}_{2} \mathrm{O}$ in $50 \mathrm{mM}\left(\mathrm{Et}_{3} \mathrm{NH}\right)_{3} \mathrm{PO}_{4}$ at $\mathrm{pH}$ 3.0. Solvent B: acetonitrile. Linear gradient, $10 \%$ to $35 \%$ of $\mathrm{B}$ in $60 \mathrm{~min}$, flow rate from $1 \mathrm{~mL} / \mathrm{min}$ to $1.5 \mathrm{~mL} / \mathrm{min}$ under UV absorption at $340 \mathrm{~nm}$. The retention times for FDAA derivatives of standard L-phenylalanine, diketopiperazine (3), and standard D-phenylalanine were observed as $35.52,35.52$, and $40.29 \mathrm{~min}$, respectively.

Single-Crystal X-ray Structure Determination. A Leica MZ7 polarizing microscope was used to identify a suitable specimen from a representative sampling of materials. A crystal of size $0.10 \times 0.10 \times$ $0.01 \mathrm{~mm}^{3}$ of $p$-hydroxyphenopyrrozin (1) crystallized in $\mathrm{MeOH}$ was fixed to a nylon loop, which in turn was fashioned to a copper-mounting pin. The mounted crystal was then placed in a cold nitrogen stream (Oxford) maintained at $110 \mathrm{~K}$. A Bruker D8 GADDS general-purpose three-circle X-ray diffractometer was employed for sample screening and data collection. The goniometer was controlled using the GADDS software suite (Microsoft Win 2000 operating system). The sample was optically centered with the aid of a video camera such that no translations were observed as the crystal was rotated through all positions. The detector was set at $5.0 \mathrm{~cm}$ from the crystal sample (MWPC Hi-Star detector, $512 \times 512$ pixel). The X-ray radiation employed was generated from a $\mathrm{Cu}$ sealed $\mathrm{X}$-ray tube $\left(\mathrm{K}_{\alpha}=1.54184\right.$ $\AA$ with a potential of $40 \mathrm{kV}$ and a current of $40 \mathrm{~mA}$ ) and filtered with a graphite monochromator in the parallel mode $(175 \mathrm{~mm}$ collimator with $0.5 \mathrm{~mm}$ pinholes). A rotation exposure was taken to determine crystal quality and the X-ray beam intersection with the detector. The beam intersection coordinates were compared to the configured coordinates, and changes were made accordingly. The rotation exposure indicated acceptable crystal quality, and the unit cell determination was undertaken. Sixty data frames were taken at widths of $0.5^{\circ}$ with an exposure time of $10 \mathrm{~s}$. Over 200 reflections were centered, and their positions were determined. These reflections were used in the autoindexing procedure to determine the unit cell. A suitable cell was found and refined by nonlinear least squares and Bravais lattice procedures and reported in Table 1 of the Supporting Information. The unit cell was verified by examination of the $h k l$ overlays on several frames of data, including zone photographs. No supercell or erroneous reflections were observed. After careful examination of the unit cell, a standard data collection procedure was initiated. This procedure consists in collection of one hemisphere of data collected using omega scans, involving the collection of $25200.5^{\circ}$ frames at fixed angles for $\phi, 2 \theta$, and $\chi\left(2 \theta=-28^{\circ}, \chi=54.73^{\circ}, 2 \theta=-90^{\circ}, \chi=54.73^{\circ}\right)$, while varying omega. Additional data frames were collected to complete the data set. Each frame was exposed for $10 \mathrm{~s}$. The total data collection was performed for a duration of approximately $24 \mathrm{~h}$ at $110 \mathrm{~K}$. No significant intensity fluctuations of equivalent reflections were observed. $R$ indices for all data $(\mathrm{R} 1=0.0623, \mathrm{wR} 2=0.1361)$ and final $R$ indices $[I>$ $2 \sigma(I)](\mathrm{R} 1=0.0525, \mathrm{wR} 2=0.1316)$ were determined. After data collection, the crystal was measured carefully for size, morphology, and color. These measurements are reported in Table 1 of the Supporting Information.
Antimicrobial Assays. MICs were determined for C. albicans (ATCC \#44506) by standard microdilution broth method using Sabouraud dextrose broth (SDB) $)^{23}$ as growth medium. MICs against $S$. aureus (ATCC \#29213) were determined using a standard microdilution broth method using cation-supplemented Mueller-Hinton broth as growth medium. All plates were incubated for $18 \mathrm{~h}$ at $37^{\circ} \mathrm{C}$.

Cytotoxicity Assays. The compounds were analyzed for their effects on proliferation of P388 murine leukemia, A549 human lung adenocarcinoma, PANC-1 human pancreatic cancer, and NCI-ADR-RES tumor cell lines. Assays were run in 96-well plates. After appropriate incubation with compound ( $45 \mathrm{~h}$ for P388 and $72 \mathrm{~h}$ for mammalian cell lines), cytotoxicity was measured spectrophotometrically using MTT as the indicator. The details of the cytotoxicity assays were described in an earlier publication. ${ }^{24}$

Acknowledgment. We are grateful to J. H. Reibenspies, Department of Chemistry, Texas A \& M University, College Station, Texas, for X-ray crystallography data, and J.H.R. would like to acknowledge the National Science Foundation for funds provided to purchase the X-ray diffractometers and crystallographic computing systems. We thank D. Powell of the University of Florida for high-resolution mass spectral measurements, K. Janda for fermentation of the fungal material, D. Harmody for antifungal assays, and P. Linley for cytotoxicity assays. We also thank A. Ledger for molecular identification of the fungal strain. The work was supported by the Center of Excellence in Biomedical and Marine Biotechnology. This publication represents Harbor Branch Oceanographic Institution Contribution No. 1625.

Supporting Information Available: X-ray crystallography data for compound $\mathbf{1}$. This material is available free of charge via the Internet at http://pubs.acs.org.

\section{References and Notes}

(1) Fusetani, N., Ed. Drugs from the Sea; Karger: Basel, 2000.

(2) Fenical, W. Chem. Rev. 1993, 93, 1673-1683.

(3) Blunt, J. W.; Copp, B. R.; Munro, M. H. G.; Northcote, P. T.; Princep, P. R. Nat. Prod. Rep. 2005, 22, 15-61, and references therein.

(4) Blunt, J. W.; Copp, B. R.; Munro, M. H. G.; Northcote, P. T.; Princep, P. R. Nat. Prod. Rep. 2004, 21, 1-49, and references therin.

(5) Shiomi, K.; Yang, H.; Xu, Q.; Arai, N.; Namiki, M.; Hayashi, M.; Inokoshi, J.; Takeshima, H.; Masuma, R.; Komiyama, K.; Omura, S. J. Antibiot. 1995, 12, 1413-1418.

(6) Omura, S.; Shiomi, K.; Komyama, H.; Masuma, R. Japan Patent $08127583,1996$.

(7) Kamikawa, T.; Higuchi, F.; Taniguchi, M.; Asaka, Y. Agric. Chem. Biol. 1980, 44, 691-692.

(8) Munekata, M.; Tamura, G. Agric. Chem. Biol. 1981, 45, 2613-2618.

(9) Jayatilake, G. S.; Thornton, M. P.; Leonard, A. C.; Grimwade, J. E.; Baker, B. J. J. Nat. Prod. 1996, 59, 293-296.

(10) Fdhila, F.; Vazquez, V.; Sanchez, J. L.; Riguera, R. J. Nat. Prod. 2003, 66, 1299-1301

(11) Li, Y.; Li, X. F.; Kim, D. S.; Choi, H. D.; Son, B. W. Arch. Pharm. Res. 2003, 26, 21-23.

(12) Carman, R. M.; Marty, R. A. Aust. J. Chem. 1966, 19, 2403-2406.

(13) Bastard, J.; Duc, D. K.; Fetizon, M.; Francis, M. J.; Grant, P. K.; Weavers, R. T.; Kaneko, C.; Baddeley, G. V.; Bernassau, J.-M.; Burfitt, I. R.; Wovkulich, P. M.; Wenkert, E. J. Nat.Prod. 1984, 47, 592-599.

(14) Crystallographic data for the structure 1 have been deposited with the Cambridge Crystallographic Data Centre. Copies of the data can be obtained, free of charge, on application to the Director, CCDC, 12 Union Road, Cambridge CB2 1EZ, UK (fax: +44-(0)-1223336033 or e-mail: deposit@ccdc.cam.ac.uk).

(15) Marfey, P. Carlsberg Res. Commun. 1984, 49, 591-596.

(16) Adamczeski, M.; Quinoa, E.; Crews, P. J. Am. Chem. Soc. 1989 , $111,647-654$

(17) Shigemori, H.; Tenma, M.; Shimazaki, K.; Kobayashi, J. J. Nat. Prod 1998, 61, 696-698.

(18) Kopple, K. D.; Marr, D. H. J. Am. Chem. Soc. 1967, 89, 61936199.

(19) Kopple, K. D.; Ohnishi, M. J. Am. Chem. Soc. 1969, 91, 962-970.

(20) Madison, V.; Young, P. E.; Blout, E. R. J.A m. Chem. Soc. 1976, $98,5358-5364$.

(21) Young, P. E.; Madison, V.; Blout, E. R. J. Am. Chem. Soc. 1976, 98, 5365-5371.

(22) Olson, J. B.; Lord C. C.; McCarthy P. J. Microb. Ecol. 2000, 40, 139-147. 
(23) Jones, R. N., Barry, D. A.; Gavan, T. L.; Washington, J. A., II. In Manual of Clinic Microbiology, 4th ed.; Lennette, E. H., Balows, A., Hausler, W. J., Shadomy, H. J. Ed.; American Society for Microbiology, Washington, DC, 1985; p 972.
(24) Gunasekera, S. P.; Zuleta, I. A.; Longley, R. E.; Wright, A. E.; Pomponi, S. A. J. Nat. Prod. 2003, 66, 1615-1617.
NP058113P 